\title{
Biology of an active methane seep on the Oregon continental shelf
}

\author{
Andrew R. Juhl*, Gary L. Taghon** \\ Oregon State University, College of Oceanography, Corvallis, Oregon 97331, USA
}

\begin{abstract}
An active sea-floor methane seep is present approximately $20 \mathrm{~km}$ off the coast of Oregon, USA, at a depth of $132 \mathrm{~m}$. Preliminary observations in 1989 suggested that biological activity near the seep was high. In analogy to other seeps, we proposed that the methane served as an energy source fueling enhanced biological productivity. In 1990, samples of pelagic and epibenthic organisms were collected near the seep and compared to collections from background sites in terms of abundance of organisms, community composition, and ratios of the stable isotopes of $\mathrm{C}, \mathrm{N}$ and $\mathrm{S}$. Vertical profiles indicated greater abundances of bacteria in the near-bottom water over the seep, but no enhancements in the abundances of several categories of microzooplankton. The $\delta^{13} \mathrm{C}$ and $\delta^{15} \mathrm{~N}$ values of benthic fishes, crustaceans and sediment organic matter were slightly but consistently lower at the seep, indicating that the seep provided a minor source of $\mathrm{C}$ and $\mathrm{N}$ to the local food web.
\end{abstract}

KEY WORDS: Food web - Methane seep - Stable isotopes

\section{INTRODUCTION}

In many locations around the world, the continental shelf is dotted with crater-like depressions (Hovland \& Judd 1988). Such 'pockmarks' are presumed to form from the expulsion of fluids, typically containing methane, from unconsolidated sediments (King \& McLean 1970). Pockmarks are generally associated with subsurface natural gas reservoirs and are common in areas with known petroleum or oil deposits, such as the North Sea. Hovland \& Judd (1988) describe a number of anecdotal reports of high abundances of organisms associated with pockmarks. It has been proposed that methane seeping from pockmarks enhances fish production in the North Sea (Hovland et al. 1985, Hovland \& Thomsen 1989). Contrary to this proposal, Dando et al. (1991) and Jensen et al. (1992) demonstrated that biomass is actually lower near several active North Sea pockmarks.

\footnotetext{
Present addresses:

- Scripps Institution of Oceanography, La Jolla, California 92093-0227, USA

- Rutgers University, Institute of Marine and Coastal Sciences, New Brunswick, New Jersey 08903-0231, USA
}

The location of an active methane seep approximately $28 \mathrm{~km}$ southwest of Coos Bay, Oregon, USA $\left(43^{\circ} 01.84^{\prime} \mathrm{N}, 124^{\circ} 39.90^{\prime} \mathrm{W}\right)$ was revealed to Oregon State University oceanographers by a local fisherman. The fisherman had seen the images of rising bubbles on his acoustic fish-finder and deduced their nature from repeated observations over a period of 7 yr. Our preliminary observations from a submersible in 1989 indicated that seeping occurred throughout the floor and walls of a 4 to $6 \mathrm{~m}$ deep pockmark. The area immediately surrounding the pockmark consisted of anoxic sediments smelling of hydrogen sulfide and covered by a thin layer of oxidized sediment. Extensive bacterial mats and large carbonate slabs were also seen in the immediate vicinity of the pockmark.

Similar carbonate formations have been found at deep-water methane seeps on the Oregon continental slope (Kulm et al. 1986). Isotopic evidence indicates that methane-derived carbon is incorporated into these carbonates (Ritger et al. 1987). These deep-water methane seeps are populated by a megafaunal community which resembles those found at hydrothermal vents (Kulm et al. 1986), including vestimentiferan tubeworms and vesicomyid clams which contain sulfide-oxidizing endosymbiotic bacteria (G. Taghon un- 
publ.). It has been proposed that bacterial sulfate reduction, using seep methane as the reducing agent, produces the sulfide necessary for the megafauna. The methane-derived $\mathrm{CO}_{2}$ then precipitates to form the carbonates (Kulm et al. 1986, Ritger et al. 1987, Suess \& Whiticar 1989). Carbonate formations have also been found at shallow-water methane seeps in the North Sea (Dando et al. 1991, Jensen et al. 1992).

Based on the observations made during the 1989 survey and on what is known about other seep systems, a more comprehensive, interdisciplinary study was conducted in 1990. The central hypothesis of the biological part of the study was that methane from the seep provides, either directly or indirectly, an energy source for the local food web. If this were the case, we expected elevated abundances of organisms near the seep. We used stable isotopes of $\mathrm{C}, \mathrm{N}$ and $\mathrm{S}$ to describe the distribution of these elements in the pockmark ecosystem. If sulfide-oxidizing or methane-oxidizing bacteria were a source of carbon for animals near the seep, the ratio of ${ }^{13} \mathrm{C} /{ }^{12} \mathrm{C}$ in the tissues of locally collected organisms would be less than if phytoplankton-derived organic matter were the only carbon source (Fry \& Sherr 1984). We expected that analysis of the S-isotope ratio of organic matter would reveal whether sulfides produced by local sulfate reduction or dissolved oceanic sulfate were the primary source of sulfur to the seep ecosystem (Fry \& Sherr 1984). Finally, ${ }^{15} \mathrm{~N} /{ }^{14} \mathrm{~N}$ of organisms within the food web would reveal their relative trophic status (Peterson \& Fry 1987).

\section{MATERIALS AND METHODS}

Samples were collected from both a manned submersible and a surface ship from the immediate vicinity of the pockmark (these will be termed seep samples) and, for comparison, from an area approximately $2.4 \mathrm{~km}$ to the north which was considered far enough away to be outside of the seep's influence (background samples).

Water-column bacteria and microzooplankton. Water samples for bacteria and microzooplankton counts were collected using bottle casts from the surface ship. Ten-liter hydrobottles were lowered on a new steel cable to depths of $10,30,60,90$ and $115 \mathrm{~m}$ (bottom depth at the site was $132 \mathrm{~m}$ ). Three vertical profiles were obtained at the seep site (Stns 1 to 3 ). The plume of methane bubbles rising from the pockmark to the sea surface could be seen on the ship's depth recorder, as could the descending cable with the attached bottles. The ship was maneuvered until the bottles were within the bubble plume before taking the samples. Two profiles were taken at the background site (Stns 4 \& 5) approximately 12 h later. While it would have been more appropriate to collect the samples closer in time to one another, this was not possible due to the constraints of supporting multiple sampling programs from a single ship.

As the hydrobottles were brought on board, they were gently mixed and then subsampled. Subsamples were collected in $125 \mathrm{ml}$ plastic bottles half-filled with $4 \%$ ice-cold glutaraldehyde, resulting in a final concentration of $2 \%$ glutaraldehyde (Sherr \& Sherr 1989). These bottles were stored in the dark at $4^{\circ} \mathrm{C}$, up to several weeks for some samples, before they were processed in the onshore laboratory.

The standard epifluorescence direct-count technique was used to enumerate bacteria and microzooplankton (Hobbie et al. 1977, Sherr \& Sherr 1989). Separate slides for bacteria and microzooplankton counts were prepared from the same $125 \mathrm{ml}$ subsample. In each case 3 replicate slides using $1.8 \mathrm{ml}$ actual volume of seawater were prepared for counting bacteria and 3 replicate slides, 2 using $11.3 \mathrm{ml}$ and 1 using $27.1 \mathrm{ml}$ of seawater, were prepared for counting microzooplankton. Samples were filtered onto black, prestained Nuclepore polycarbonate membrane filters, $0.2 \mu \mathrm{m}$ pore size for bacteria and $1.0 \mu \mathrm{m}$ pore size for microzooplankton. Filters for enumerating bacteria were stained with 4',6-diamidino-2-phenylindole (DAPI Porter \& Feig 1980) and filters for enumerating larger organisms were stained with both DAPI and primulin (Caron 1983, Martinussen \& Thingstad 1989). Autotrophs, which could be distinguished by autofluorescence of chlorophyll, were not enumerated. See Juhl (1991) for a more detailed description of the method.

All slides were stored in the dark at $-20^{\circ} \mathrm{C}$. Slides stored in this manner will keep for months without deteriorating (Porter \& Feig 1980, Bloem \& Baer Gilissen 1988). A Zeiss epifluorescence microscope (blue exci tation: Zeiss filter set 487709, exciter filter BP 450-490, chromatic beam splitter FT 510, barrier filter LP 520; UV excitation: Zeiss filter set 487701 , exciter filter BP 365/12, chromatic beam splitter FT 395, barrier filter LP 397) was used to enumerate the organisms on the slides. Bacteria and $<10 \mu \mathrm{m}$ organisms were counted at $1000 \times$ magnification, 10 to $24 \mu \mathrm{m}$ organisms at $400 \times$, and $>24 \mu \mathrm{m}$ organisms at $250 \times$.

Stable isotope analysis. Samples of organisms, sediment and water-column particulate matter were collected for stable isotope analysis.

Epibenthic fishes and shrimps were collected near the seep and at a background site using an otter trawl (collection supervised by D. Stein and J. Fisher). For fishes, only muscle tissues exclusive of scales, skin and internal organs were analyzed. Whole shrimps minus their viscera and exoskeleton were analyzed; stomach contents were removed and analyzed separately. 
Fig. 1 Abundance of $>40 \mu \mathrm{m}$ microzooplankton. Each panel corresponds to 1 taxon. Data points for different stations are offset slightly to minimize the degree to which points at the same depth overlap. Open symbols represent vent samples ( $\square: \operatorname{Stn} 1 ; 0: \operatorname{Stn} 2$; $\triangleright: \operatorname{Stn} 3$ ) while closed symbols represent back-ground samples (-: Stn $4, \bullet: \operatorname{Stn} 5$ )
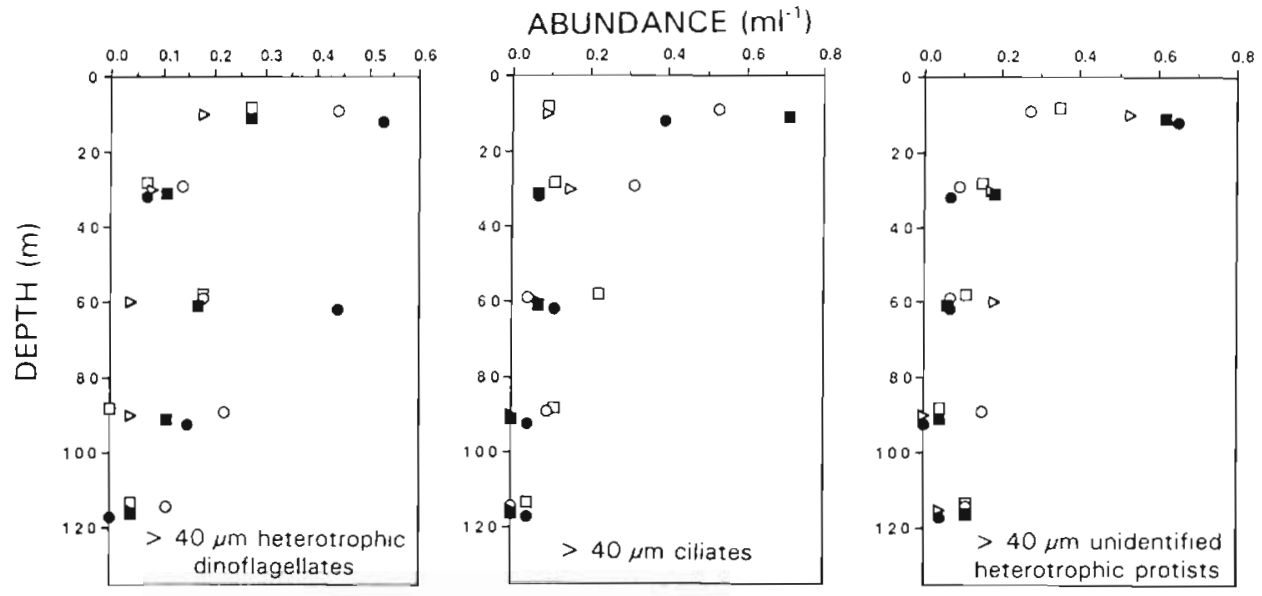

Several large anemones (Metridium sp.) which were attached to samples of carbonate rocks brought up from the seep, were collected. Body-wall muscles from these anemones were analyzed.

Sediment samples were collected by the submersible from the seep and a background site. A submersiblemounted slurp gun was used to collect bacterial mats at the seep.

Water-column particulates were collected on Whatman GF/C filters. Because of financial constraints only 1 sample each from the seep and the background site were analyzed. Several samples were pooled in order to amass sufficient material. In total, the particulate matter which could be collected from 40 l of water was analyzed for each of the 2 sites. After subsampling for the microbial population, the contents of hydrobottles from 90 and $115 \mathrm{~m}$ from Stns 2 \& 3 for the seep sample and Stns $4 \& 5$ for the background sample were filtered after prescreening through a $200 \mu \mathrm{m}$ mesh net.

All samples were analyzed for stable isotopes of carbon, and those which had sufficient material were also analyzed for stable isotopes of nitrogen and sulfur. Stable isotope analysis has been used in a wide range of ecological studies (see review in Petersen \& Fry 1987). The values of stable isotope ratios are reported in standard $\delta$ notation as parts per thousand (ppt) difference relative to an established standard. The standard for carbon is PeeDee Belemnite (a limestone deposit), the nitrogen standard is the atmospheric reservoir of $\mathrm{N}_{2}$ and the standard for sulfur is the Canyon Diablo meteorite. Typical measurement precision is usually 0.1 to $0.2 \mathrm{ppt}$.

All samples collected for stable isotope analysis were immediately frozen upon collection. Later they were either freeze-dried or dried at $60^{\circ} \mathrm{C}$ in an oven. Where necessary, the samples were acidified to remove carbonate. All samples were analyzed by Coastal Science Laboratories, Inc. The $\delta^{13} \mathrm{C}$ for the methane gas and seep carbonates were provided by R. Collier, A. Ungerer and L. Kulm.

\section{RESULTS}

\section{Microzooplankton counts}

Microzooplankton were split into 4 size classes, $>40$, 24 to 40,10 to 24 and $<10 \mu \mathrm{m}$. The 3 largest classes were additionally separated into the 3 taxonomic categories of heterotrophic dinoflagellates, ciliates and other heterotrophic protists; the 10 to $24 \mu \mathrm{m}$ size class had the additional category of choanoflagellates. The smallest microzooplankton (the $<10 \mu \mathrm{m}$ size class) were counted as a single category.

The general pattern was similar for organisms within the 3 largest size classes (Figs. 1 to 3 ). Abundance was highest by as much as an order of magnitude near the surface and then generally declined with depth. Across-depth comparisons, particularly at the greatest depths, would be the most straightforward way of finding differences between the seep and background sites. Only near the surface did large differences occur consistently between the 2 sites in several groups of organisms; the background abundance was higher than the seep stations in several cases. At the other depths one cannot distinguish between the seep and background stations based on these 3 largest classes of microzooplankton.

Size structure within the planktonic community is important in determining carbon flow pathways (e.g. Carpenter et al. 1987). In order to see more clearly any potential changes within the size structure of the communities present at both sites, all organisms were separated into the same 4 size classes above but were not separated taxonomically. The same patterns were evident despite the lumping (Fig. 4). 

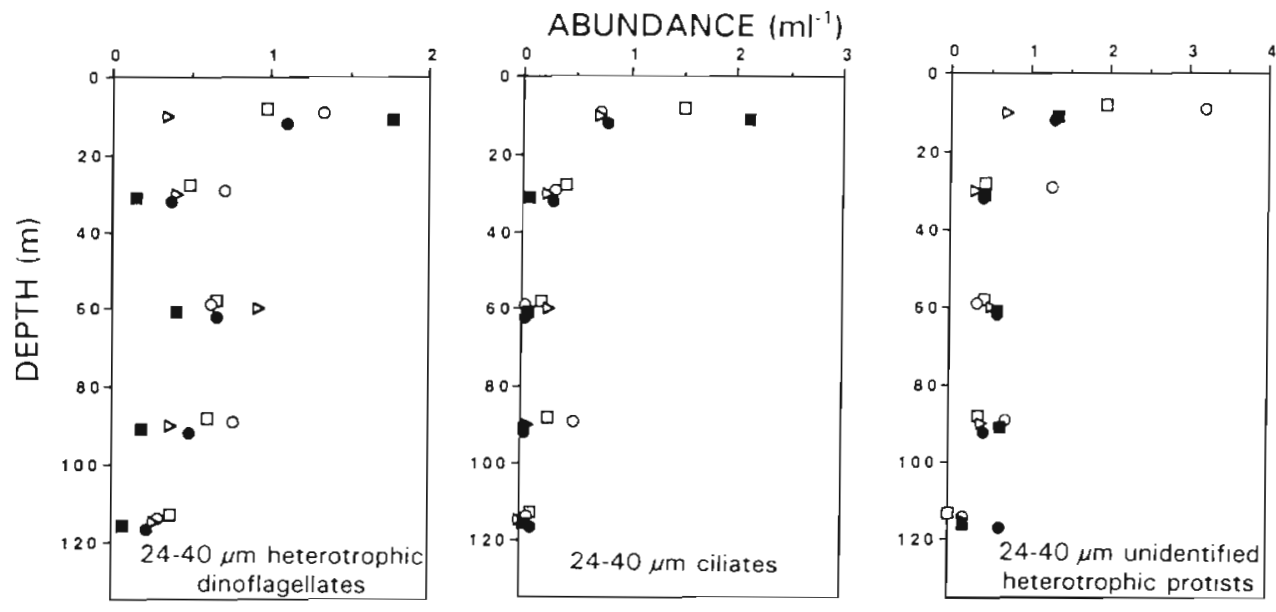

Fig. 2. Abundance of 24 to $40 \mu \mathrm{m}$ microzooplankton. Symbols as in Fig. 1

The $<10 \mu \mathrm{m}$ size class consisted almost entirely of $<4$ $\mu \mathrm{m}$ heterotrophic flagellates. Their abundance was quite high at both sites compared to typical oceanic values (Fig. 5). Within the seep stations, there was a trend towards increased abundance at depth relative to the background values. This trend was not statistically significant for any of the stations except Stn 1. The mean abundance determined at the greatest depth $(115 \mathrm{~m})$ for Stn 1 was significantly greater than the combined mean of the background stations at the 0.01 level ( $t$-test).

\section{Water-column bacteria counts}

Abundance at the background stations was highest at the surface and declined steadily with depth, with the near-surface value approximately twice that of the deepest sample (Fig. 6). Similar to the $<10 \mu \mathrm{m}$ heterotrophs, the abundance of water column bacteria at the seep was high relative to background at the greatest depth $(115 \mathrm{~m})$. In this case, however, the relationship was stronger; at the $115 \mathrm{~m}$ depth the combined mean of all the seep samples was significantly greater than the combined mean of the background samples at the 0.01 level (t-test).

\section{Stable isotopes}

$\delta^{13} \mathrm{C}$ and $\delta^{15} \mathrm{~N}$ values of organisms and organic matter in the water column and sediments from the seep area were consistently less (lighter) than similar samples from the background site (Table 1). This difference was statistically significant (1-tailed Wilcoxon signed-ranks test: $\mathrm{p}=0.016$ for $\delta^{13} \mathrm{C}$ values and $\mathrm{p}=$ 0.039 for $\delta^{15} \mathrm{~N}$ values). Interestingly, the 2 exceptions to the trend were juvenile fishes. The lowest $\delta^{13} \mathrm{C}$ value was from the bacterial mat. The range of values for

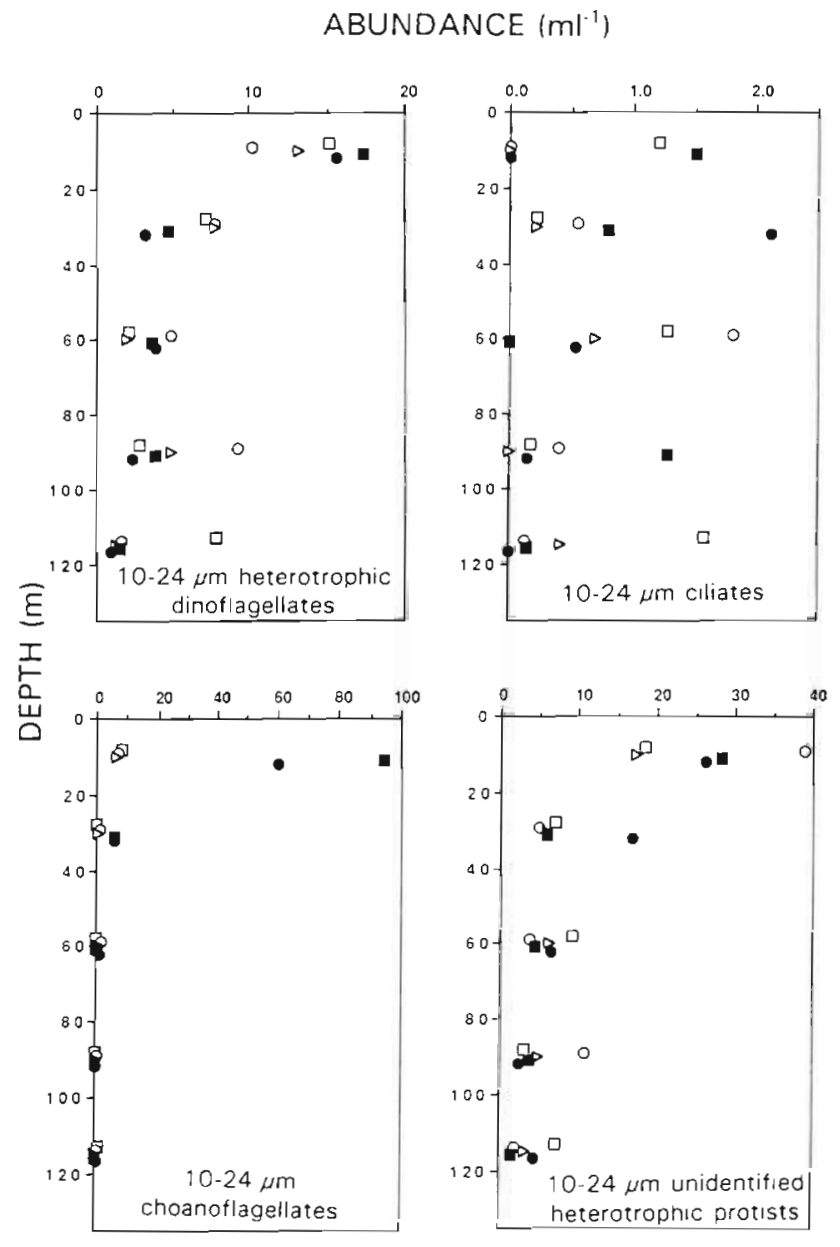

Fig. 3. Abundance of 10 to $24 \mu \mathrm{m}$ microzooplankton. Symbols as in Fig. 1

$\delta^{15} \mathrm{~N}$ was lower than expected since the samples from the 2 sites were predicted to span several trophic levels.

There was not a significant difference between the 
Fig. 4. Abundance of large microzooplankton. All taxa within a size class have been lumped together. Symbols as in Fig. 1
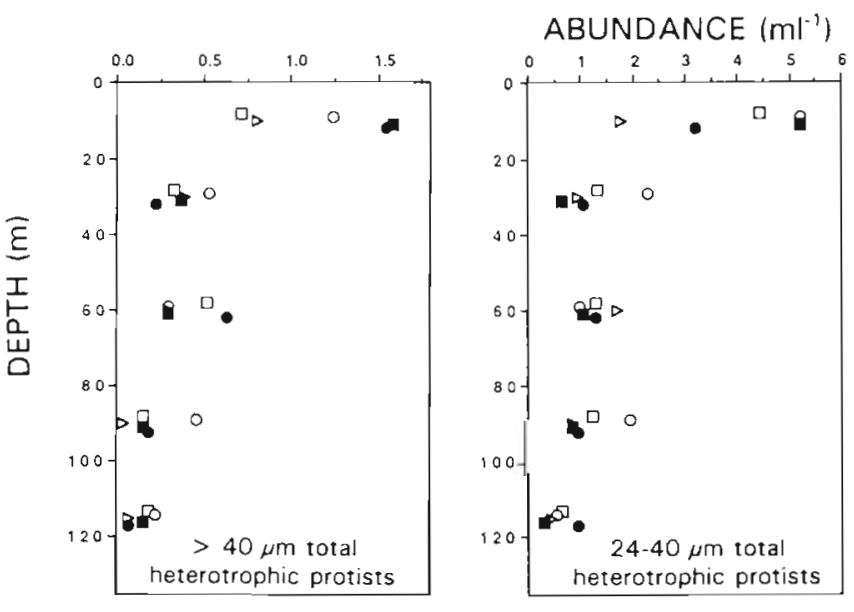

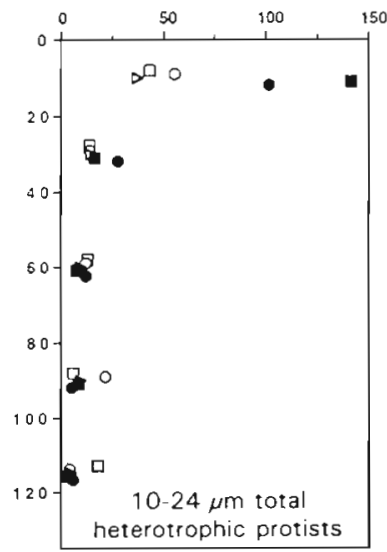

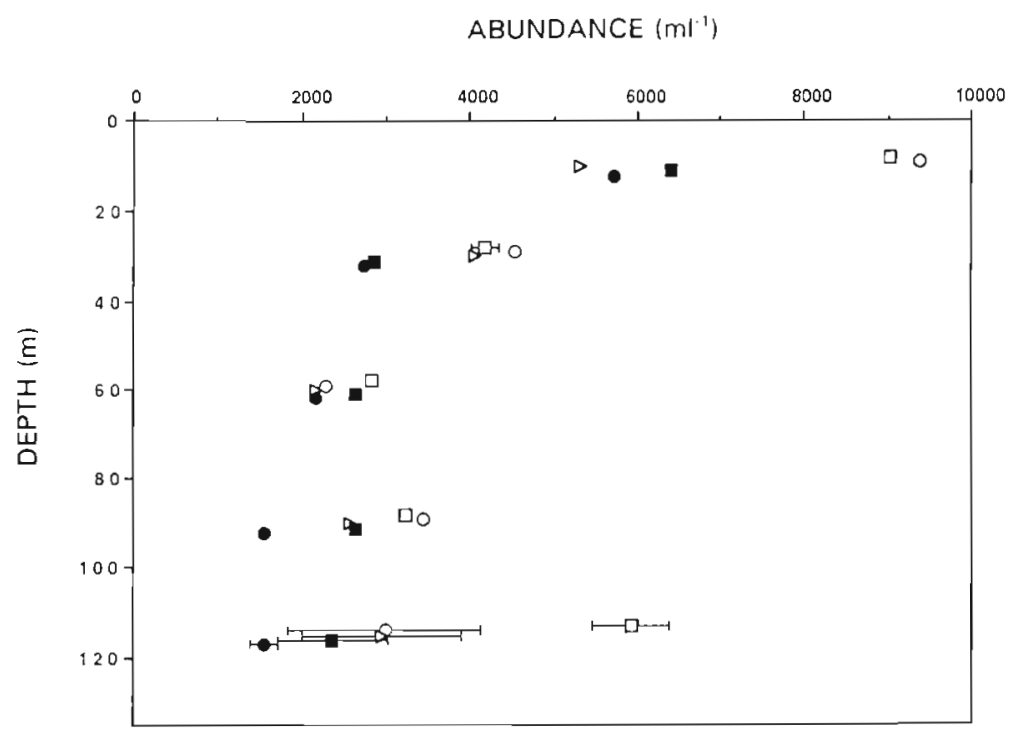

Fig. 5. Abundance of $<10 \mu \mathrm{m}$ heterotrophic protists. Symbols as in Fig. 1 Where present, error bars represent one standard deviation calculated from replicate slides ( 2 or 3 ) of the same seawater sample bottom. The highest concentration of methane in the water column was approximately $175 \mathrm{nM}$ in 1990, ca 8 times above background but much less than a value of $>700$ nM measured in 1989 (Taghon et al. 1990). This corresponds to our subjective impressions, based on direct observations from a submersible, that the seep was less active in 1990 than in 1989.

Abundances of bacterioplankton and $<10 \mu \mathrm{m}$ heterotrophs were greater in the bottom water directly over the pockmark, relative to the background stations. While this trend was exactly what one would predict if the seep methane was promoting microbial activity, we believe that these results are not good evidence for an important enhancement of biological activity due to the seep. The increase in abundance at the seep stations was small relative to the range seen in natural microbial populations. Estimates of natural abundance of small marine flagellates (Porter et $\delta^{34} \mathrm{~S}$ values of seep and background samples (Table 1). Except for the anemone collected near the seep, all values from both sites were lower than would be predicted for typical oceanic organic matter $(+17$ to +21 ppt; Peterson \& Fry 1987).

\section{DISCUSSION}

Water-column profiles showed, not surprisingly, that the highest methane concentrations were directly over the seep (R. Collier \& M. Lilley unpubl.). Methane concentration was also considerably higher downstream from the seep than upstream. At both the seep and the downstream site, elevated methane concentrations persisted in the water column for at least $50 \mathrm{~m}$ above al. 1985) and free-living bacterioplankton (Ducklow 1983) vary over several orders of magnitude. Bacterial abundance may reach $10^{9}$ cells $\mathrm{ml}^{-1}$ near hydrothermal vents (Corliss et al. 1979). Compared to this potential, the increase we observed was minor.

Bacterial productivity was not measured but could have been higher near the seep than at background stations if predation was higher at the seep. One would predict that this would result in higher standing stocks of bacterivorous microzooplankton, unless they were also being consumed, and so on up the food chain. While this scenario is possible, it seems unlikely. The microorganisms enumerated varied in size over 3 orders of magnitude, spanned several trophic levels and almost certainly covered a wide range of growth rates. If bacterial productivity was enhanced substantially at 
the seep, one would expect to see some organisms within the microbial food chain outstrip their predators' ability to consume them.

Because of the time lag between the collection of the seep and background samples it is possible that the background samples do not truly represent the background microbial community at the time the seep samples were collected. While this possibility cannot be excluded, the similarity, particularly at depth, between the 2 sets of counts of large microzooplankton leads us to believe that the same microbial community was sampled.

The benthic environment may be the most likely place to find an influence of the seep. The concentration of methane was several orders of magnitude greater in porewaters than in the water column (up to $1300 \mu \mathrm{m}$ in 1990) and high rates of aerobic methane oxidation were measured in the pockmark sediments $(R$. Collier \& M. Lilley unpubl.). Unfortunately, due to equipment failure, no samples of benthic infauna were collected. Collections of epibenthic fishes and crustaceans made at the seep and at background sites with an otter trawl revealed no influence of the pockmark on the abundance of any fish species or on total abundance (D. Stein unpubl.).

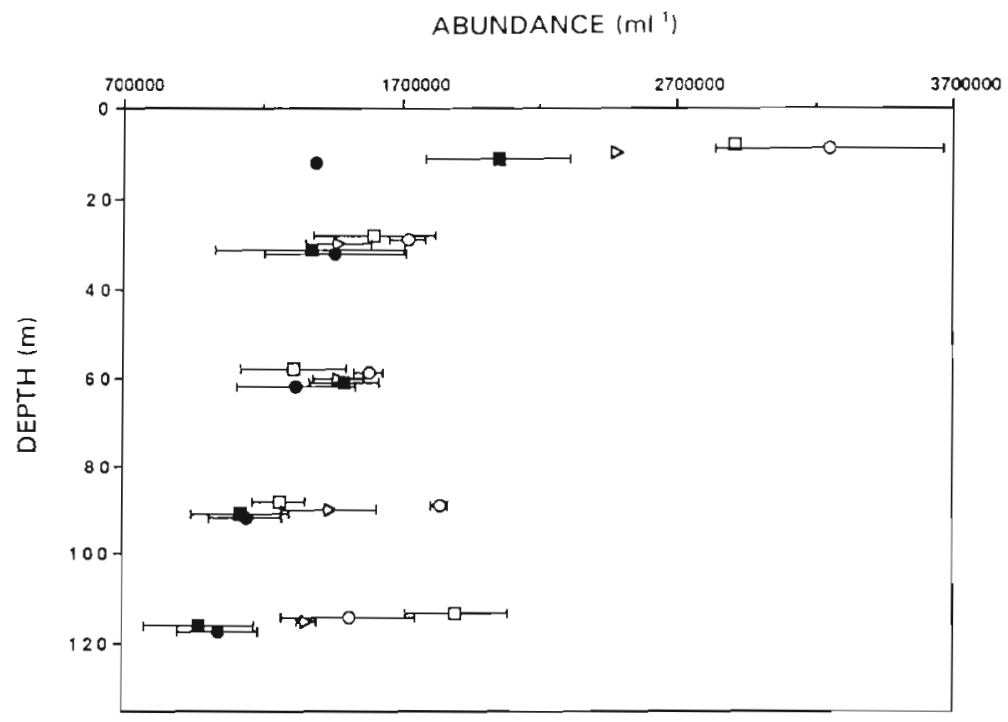

Fig. 6. Abundance of heterotrophic, free-living water column bacteria. Symbols as in Fig. 1. Where present, error bars represent 1 standard deviation calculated from replicate slides (usually 3 ) of the same seawater sample

The stable carbon isotope signatures of epibenthic samples indicate that the seep provided a minor source of light carbon to local organisms (Table 1). Typically, marine organic matter has a $\delta^{13} \mathrm{C}$ of -18 to -24 ppt (Fry \& Sherr 1984), reflecting the carbon isotope ratio of phytoplankton. Methane from the seep has a $\delta^{13} \mathrm{C}$ of -29 ppt (Lilley et al. 1990), an unusually high value for

Table 1 Stable isotope analyses. Unless indicated, only single samples were available for analysis. Mean (SD) reported for species where 2 samples were analyzed. -: no data. POM: particulate organic matter; OM: organic matter

\begin{tabular}{|c|c|c|c|c|c|c|}
\hline \multirow[t]{2}{*}{ Sample } & \multicolumn{2}{|c|}{$\delta^{13} \mathrm{C}$} & \multicolumn{2}{|r|}{$\delta^{15} \mathrm{~N}$} & \multicolumn{2}{|c|}{$\delta^{34} \mathrm{~S}$} \\
\hline & Vent & Background & Vent & Background & Vent & Background \\
\hline Water-column POM & -24.3 & -23.5 & - & - & - & - \\
\hline Sediment $O M$ & -23.7 & -22.7 & - & - & - & - \\
\hline Bacterial mat & -24.7 & - & - & - & - & - \\
\hline \multicolumn{7}{|c|}{ Small shrimp Crangon communis } \\
\hline Body tissue (2) & $-17.4(0.3)$ & $-16.3(0.6)$ & $13.7(0.4)$ & $14.4(0.1)$ & $7.8(0.2)$ & $11.1(0.0)$ \\
\hline Stomach & -22.4 & -22.4 & 12.2 & 12.7 & - & - \\
\hline \multicolumn{7}{|c|}{ Pink shrimp Pandalus jordani } \\
\hline Body tissue (2) & $-18.8(0.1)$ & $-18.2(0.6)$ & $12.8(0.1)$ & $13.4(0.4)$ & $14.1(0.7)$ & $13.7(0.3)$ \\
\hline Stomach (2) & $-23.2(0.6)$ & - & $1.1 .8(0.4)$ & - & $13.6(0.1)$ & - \\
\hline Stomach & - & -23.2 & - & 12.6 & - & - \\
\hline \multicolumn{7}{|l|}{ Adult flounder } \\
\hline Atheresthes stomias & -19.6 & - & 13.8 & - & 11.5 & - \\
\hline \multicolumn{7}{|l|}{ Adult rockfish } \\
\hline Sebastes elongatus & -19.5 & -19.1 & 15.0 & 15.0 & 13.8 & 14.9 \\
\hline \multicolumn{7}{|l|}{ Adult slender sole } \\
\hline Lyopsetta exilis & -19.5 & -17.6 & 13.8 & 15.4 & 14.1 & 8.5 \\
\hline $\begin{array}{l}\text { Juvenile slender sole } \\
\text { Juvenile rex sole }\end{array}$ & -19.7 & -19.7 & 12.1 & 12.0 & 14.3 & 15.3 \\
\hline Cilyptocephalus zachirus & -18.4 & -18.4 & 15.6 & 15.3 & 6.2 & 11.1 \\
\hline \multicolumn{7}{|l|}{ Anemone } \\
\hline Metridium spp. & -19.2 & - & 14.9 & - & 18.0 & - \\
\hline
\end{tabular}


methane. A possible explanation is that the seeping gas represented the remnant of a subsurface reservoir which had been extensively oxidized during its upward migration through the sediments, as hypothesized by Suess \& Whiticar (1989) for deeper seeps on the Oregon margin. Thus the slight shift in carbon isotope values in samples from the seep may indicate a contribution from the methane. The high methane oxidation rates support this scenario. Alternatively, sulfide-oxidizing bacteria could also serve as a source of ${ }^{13} \mathrm{C}$-depleted organic matter (Ruby et al. 1987), as occurs at other seep sites. Although the $\delta^{13} \mathrm{C}$ values of seep samples are lower than the corresponding background samples, the magnitude of the difference reveals that the light carbon end-member serves as a minor source of carbon to the seep fauna. The primary source of carbon was most likely phytoplankton.

The $\delta^{15} \mathrm{~N}$ values of the majority of seep samples were lower than the corresponding background samples. Nitrogen isotopes are primarily used as information on trophic status and it cannot be predicted what values of $\delta^{15} \mathrm{~N}$ one might find in a system. Therefore, the consistent difference in nitrogen isotopes can be interpreted in 2 ways; either the organisms near the seep were feeding slightly lower in the food web, or, more likely, there was a different nitrogen end-member near the seep. For example, a decrease in the rate of denitrification near the seep would result in a lower $\delta^{15} \mathrm{~N}$ value for the local nitrate reservoir. The sediment porewaters near the seep are highly enriched with $\mathrm{NH}_{4}{ }^{+}(\mathrm{R}$. Collier \& M. Lilley unpubl). Although this does not relate directly to the question of whether seep-derived materials and energy were entering the local food web it does indicate that there was a difference between the seep and background sites.

The seep was distinguishable from the surrounding area by the expulsion of gas and by the presence of bacterial mats and carbonate formations. However, we found no evidence of increased abundances of microzooplankton, macrozooplankton, or fishes. There may be a slight increase in abundance of bacterioplankton associated with the seep plume. The isotope data indicate that the seep provided a limited source of light $\mathrm{C}$ and $\mathrm{N}$ for the local food web. Although detectable, these seep-associated sources of $\mathrm{C}$ and $\mathrm{N}$ are minor, which is the best explanation for the lack of an increase in the abundances of animals. This is essentially the same conclusion reached by Dando et al. (1991) in their study of a North Sea pockmark. The lack of a seep effect on local foodwebs in these 2 studies of shallowwater methane seeps provides an intriguing contrast to deep-water seeps on the Oregon continental rise. There may be considerable temporal variation in ebullition rates of shallow and deep seeps. Since the background organic loading in shallow nearshore waters is high, relative to deeper waters, it may be that only during periods of highest activity do shallow seeps provide a source of energy which is large compared to the background.

Acknowledgements. This research was supported by NOAA's National Undersea Research Program and the West Coast National Undersea Research Center at the University of Alaska, Fairbanks.

\section{LITERATURE CITED}

Bloem, J., Baer Gilissen, M. B. (1988). Fixing nanoflagellates. Arch. Hydrobiol. Beih. Ergeb. Limnol. 31: 275-280

Caron, D. A. (1983). Technique for enumeration of heterotrophic and phototrophic nanoplankton, using epifluorescence microscopy, and comparison with other procedures. Appl. environ. Microbiol. 46: 491-498

Carpenter, S. R., Kitchell, J. F., Hodgson, J. R., Cochran, P. A., Elser, J. J., Elser, M. M., Lodge, D. M., Kretchmer, H. X., von Ende, C. N. (1987). Regulation of lake primary productivity by food web structure. Ecology 68: $1863-1876$

Corliss, J. B., Dymond, J., Gordon, L. I., Edmond, J. M., von Herzen, R. P., Ballard, R. D., Green, K., Williams, D., Bainbridge, A., Crane, K., van Andel, T H. (1979). Submarine thermal springs on the Galapagos rift. Science 203: 1073-1083

Dando, P. R., Austen, M. C., Burke, R. A. Jr, Kendall, M. A., Kennicutt, M. C. II, Judd, A. G., Moore, D. C., O'Hara, S. C. M., Schmaljohann, R., Southward, A. J. (1991). Ecology of a North Sea pockmark with an active methane seep. Mar. Ecol. Prog. Ser. 70: 49-63

Ducklow, H. (1983). The production and fate of bacteria in the oceans. Biosci. 33: 494-501

Fry, B., Sherr, E. B. (1984). $\delta^{13} \mathrm{C}$ measurements as indicators of carbon flow in marine and freshwater ecosystems. Contr mar. Sci. 27: 13-47

Hobbie, J. E., Daley, R. J., Jasper, S. (1977). Use of Nuclepore filters for counting bacteria by fluorescence microscopy. Appl. environ. Microbiol 33: 1225-1228

Hovland, M., Judd, A. G. (1988). Seabed pockmarks and seepages. Graham and Trotman, Boston

Hovland, M., Judd, A., Maisey, G. (1985). North Sea gas feeds the North Sea fisheries. New Scient. 107: 26

Hovland, M., Thomsen, E. (1989). Hydrocarbon-based communities in the North Sea? Sarsia 74:29-42

Jensen, P., Aagaard, I., Burke, R. A. Jr, Dando, P. R., Jorgensen, N. O., Kuijpers, A., Laier, T., O'Hara, S. C. M., Schmaljohann, R. (1992). 'Bubbling reefs' in the Kattegat: submarine landscapes of carbonate-cemented rocks support a diverse ecosystem at methane seeps. Mar. Ecol. Prog. Ser. 83: 103-112

Juhl, A. (1991). The biology of a shallow-water methane vent. M.S. thesis, Oregon State University, Corvallis

King, L. H., McLean, B. (1970). Pockmarks on the Scotian shelf. Bull. geol. Soc. Am. 81. 3141-3148

Kulm, L. D., Suess, E., Moore, J. C., Carson, B., Lewis, B. T., Ritger, S. D., Kadko, D. C., Thornburg, T. M., Embley, R. W., Rugh, W. D., Massoth, G. J., Langseth, M. G., Cochrane, G. R., Scamman, R. L. (1986). Oregon subduction zone: venting, fauna, and carbonates. Science 231: $561-566$ 
Lilley, M. D., Devol, A. H., Collier, R. W., Simoneit, B. R. T., Kulm, L. D. (1990). Chemical and microbiological studies at a 'pockmark' on the Oregon shelf. Trans. Am. geophys. Un. 71: 1420

Martinussen, I., Thingstad, T. F. (1989). A simple double staining technique for quantification of nano- and picoplankton. In: Protozoa and their role in marine processes. NATO Advanced Study Institute, Plymouth Marine Laboratory and Plymouth Polytechnic, 24 July-5 August, 1988, Abstracts

Peterson, B. J., Fry, B. (1987). Stable isotope studies in ecosystem studies. A. Rev. Ecol. Syst. 18: 293-320

Porter, K. G., Feig, Y S. (1980). The use of DAPI for identifying and counting aquatic microflora. Limnol. Oceanogr. 25: $943-948$

Porter, K. G., Sherr, E. B., Sherr, B. F., Pace, M., Sanders, R. W. (1985). Protozoa in planktonic food webs. J. Protozool. 32: 409-415

Ritger, S., Carson, B., Suess, E. (1987). Methane-derived authigenic carbonates formed by subduction-induced pore-

This article was presented by B. \& E. Sherr, Corvallis, Oregon, USA water expulsion along the Oregon/Washington margin Bull geol. Soc. Am. 98: 147-156

Ruby, E. G., Jannasch, H. W., Deuser, W. G. (1987). Fractionation of stable carbon isotopes during chemoautotrophic growth of sulfur-oxidizing bacteria. Appl. environ. Microbiol. 53: 1940-1943

Sherr, E., Sherr, B. (1989). Enumeration of marine protozoa by epifluorescence microscopy. In: Protozoa and their role in marine processes. NATO Advanced Study Institute, Plymouth Marine Laboratory and Plymouth Polytechnic, 24 July-5 August, 1988, Abstracts

Suess, E., Whiticar, M. J. \{1989\}, Methane-derived $\mathrm{CO}_{2}$ in pore fluids expelled from the Oregon subduction zone. Paleogeogr. Paleoclimatol. Paleoecol. 71: $119-136$

Taghon, G., Stein, D., Pearcy, W., Ungerer, A., Kulm, L., Collier, R. (1990). Enhanced biological productivity at an active methane vent (pockmark) on the Oregon continental shelf. Trans. Am. geophys. Un. 71: 192

Manuscript first received: October 1, 1992

Revised version accepted: April 16, 1993 